\title{
Biogas Energy Production Potential of Grass under Anaerobic Digestion: Review
}

\author{
Yalemtsehay Debebe ${ }^{1 *}$ and Girma Gonfa ${ }^{2}$ \\ ${ }^{1}$ Jimma agricultural Research center, Ethiopia \\ ${ }^{2}$ Addis Ababa Science and Technology University, Ethiopia
}

Submission: March 25, 2019; Published: April 24, 2019

"Corresponding author: Yalemtsehay Debebe, Jimma agricultural Research center P.O. box 192 Jimma, Ethiopia

\begin{abstract}
Because of the recent increase demand of energy, interest in environmental issues and depletion of fossil fuel, the demand of renewable energy sources as substitute of fossil fuel is rapidly increasing. Production of biogas under anaerobic digestion as methane can be used to replace nonrenewable energy resources in both heat and power generation and as a vehicle. For biogas production various organic feedstocks are used. Most often used are animal manure, food waste, agricultural wastes and crop residues, aquatic waste, forest residues, municipal solid wastes and grass. The review is based on secondary data obtained through various sources such as textbooks, journals, documents and conference papers with the objective of providing an overview of biogas energy production from biomass, thus providing information toward anaerobic digestion contributing to methane rich biogas production. The review shows that biogas production from biomass as a good fuel alternative because the source biomass can be grown renewably and decrease environmental stress.
\end{abstract}

Keywords: Anaerobic digestion; Biogas; Methane; Feedstocks

\section{Introduction}

Energy is an essential factor in development since it stimulates and supports a country's economic growth and development [1]. The global energy demand is growing rapidly, and about $88 \%$ of this demand is met at current time by fossil fuels. The depletion of fossil fuel and the impact of greenhouse gases on the environment initiated the concern in searching and exploring alternative sources of energy [2]. These sources are described as renewable energies such as solar energy, wind energy, different thermal and hydro sources of energy, and biomass [3]. Biomass residues available from agricultural and forest processing constitute a potential source for biofuel production. Currently there exist five forms of biofuels such as bioethanol, biodiesel, biomethanol, biohydrogen and biogas [4].

The production of methane rich biogas (biomethane) involves a complex biochemical reaction that takes place under anaerobic conditions in the absence of oxygen and the presence of highly $\mathrm{pH}$ sensitive microbiological catalysts that are mainly bacteria [5]. The anaerobic digestion process is a fermentation process where organic raw materials such as manure, food waste, and sewage sludge, organic industrial waste and energy crops used as substrates for biogas production. From energy crops the grass has the greatest potential for biogas production $(587.5 \mathrm{~m} 3$ methane production/tone of dry organic matter) [6]. The production of biogas through anaerobic digestion offers several environmental advantages compared to fossil fuels, because available and cheap resources to feedstock, relatively easy and cheap technology for production, extra values of digestate as a fertilizer [7], avoiding health problems, reduce greenhouse gas (GHG) emissions, reduce deforestation, reduce workload from women and children [8]. The objective of this review is to provide an overview of biogas energy production from biomass, thus providing information toward anaerobic digestion contributing to methane rich biogas production.

\section{Biogas Energy Production Under Anaerobic Digestion}

Anaerobic digestion is a natural decomposition processes in which microorganisms break down biodegradable material in the absence of oxygen [3]. Anaerobic digestion is widely used as a renewable energy source because the process produces a methane and carbon dioxide rich biogas suitable for energy production, helping to replace fossil fuels. The nutrient-rich digestate which is also produced can be used as fertilizer. Fig .1 shows that the digestion process begins with bacterial hydrolysis of the input materials in order to break down insoluble organic polymers such as carbohydrates and make them available for other bacteria. Acidogenic bacteria then convert the sugars and amino acids into carbondioxide, hydrogen, ammonia, and organic acids. Acetogenic 
bacteria then convert these resulting organic acids into acetic acid, along with additional ammonia, hydrogen, and carbon dioxide. Finally, methanogens convert these products to methane and carbon dioxide [9] (Figure 1).

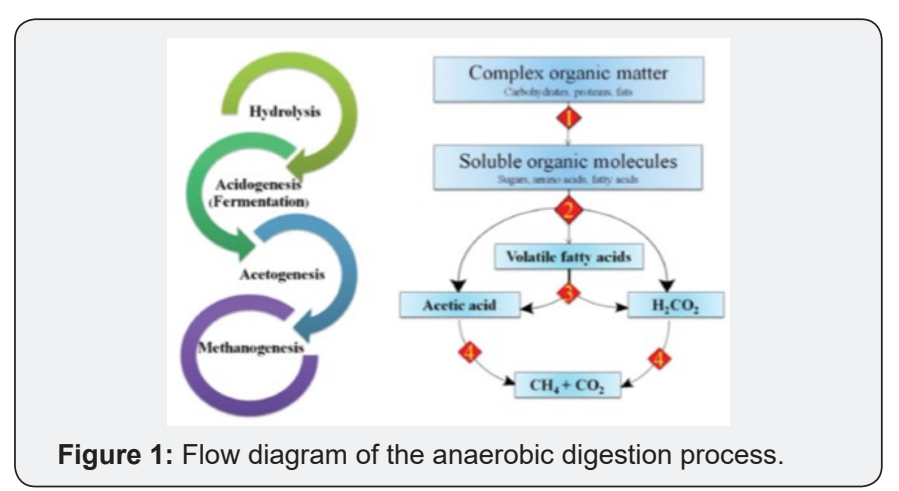

Substrates for Biogas Energy Production

Biogas can be produced from biodegradable substrates such as animal manure, food waste, agricultural wastes and crop residues, aquatic waste, forest residues and municipal solid wastes [10]. According to [11] a brief description of the various feedstocks is provided in this section.

\section{Animal manure}

Animal manure is considered a promising way for biogas production and fertilizers through the anaerobic digestion process [12]. There are significant populations of livestock in many countries. Livestock produce large amounts of manure which are suitable substrates for AD. Manure is a mixture of faeces and urine, and its chemical composition varies markedly depending on the chemical characteristics of the feed consumed by the animal. Animal manure comprises huge amounts of lignocelluloses, polysaccharides, proteins, and other biomaterials.

\section{Municipal solid waste (MSW) and food waste}

The food industry and municipal authorities produce a wide range of lignocellulosic waste types. These include food waste and municipal waste which can be used as substrates for biogas [2].

\section{Crops and their residues}

A number of crops and activities produce residues that can be used as a feedstock for biogas production [10]. Many forage and sugar beets, due to their high organic dry matter yield per hectare which produce high biogas yield [13]. Biogas also produced from non- food crops like Justicia schimperiana (Hochst. ex A. Nees) T. Ander (JS) [14].

\section{Sewage sludge}

Production of biogas from sewage sludge provides dual benefits such as biogas energy and waste management [11].

\section{Biogas Energy Production from Grass}

Compared with other feedstocks, grass has suitable and promising characteristics as energy. Crop for biogas production due to their fastest growing rates even in infertile land, low cultivation costs, higher accessibility, and consumption of whole plants. In addition, the usage of grassland as a renewable source of energy during biogas production will provide considerable quantity of environment protection, owing to the capability of grass to sequester carbon into the soil [15].

\section{Biogas production potential of napier grass}

Napier grass is a complex material that is composed of cellulose, hemicellulose and lignin. Commonly, cellulose and hemicellulose primarily contain glucose and xylose, respectively. They can be fermented to produce renewable energy using several microbial processes [16]. As shown in Table 1, the maximum methane content and methane yield of $5 \%$ and $122.4 \mathrm{ml} \mathrm{CH} 4 / \mathrm{g}$ TVS remove was obtained using napier grass as the substrate [17].

Table 1: Summary of kinetics methane production parameters at varying total solid content.

\begin{tabular}{|c|c|c|c|}
\hline TS (\%) & $\mathbf{H m}(\mathbf{m l})$ & $\mathbf{R m}(\mathbf{m l} / \mathbf{h})$ & Yield (CH4/g TVS) \\
\hline 5 & $354.1 \pm 12.4$ & $4.8 \pm 0.2$ & $122.4 \pm 5.2$ \\
\hline 10 & $167.8 \pm 15.2$ & $2.8 \pm 0.3$ & $91.2 \pm 9.1$ \\
\hline 15 & $27.8 \pm 1.67$ & $0.3 \pm 0.01$ & $52.6 \pm 0.6$ \\
\hline
\end{tabular}

Source: [17].

\section{Biogas production potential of vetiver grass}

Vetiver (Vetiveria zizanioides) is a perennial tufted grass belonging to the Poaceae family and the common domesticated cultivars used around the world are non-invasive. It has become known as a miracle grass with diverse environmental applications, including: a source of scented oil from its roots, fodder for livestock, soil and water conservation, rehabilitation, remediation, waste water treatment and a raw material for biogas production [18].

Experiment conducted in China on vetiver grass as raw material for biogas production and the result point out that the production potential of biogas were $310 \mathrm{~mL}$.Ts and $332 \mathrm{Ml} / \mathrm{g}$. vs of the grinding process group and 322 and 349 of the shearing process group [19] (Table 2).

Table 2: Biogas production potential of transenic vetiveria Zizaniodies in anaerobic digestion.

\begin{tabular}{|c|c|c|c|c|c|}
\hline \multicolumn{1}{|c|}{ Sorts } & Net gas production (mL) & $\begin{array}{c}\text { TS gas production } \\
\text { rate (mL/g.TS) }\end{array}$ & $\begin{array}{c}\text { VS gas production rate } \\
\text { (mL/g.VS) }\end{array}$ & $\begin{array}{c}\text { Tank volume gas produc- } \\
\text { tion rate (mL/mL.d) }\end{array}$ & $\begin{array}{c}\text { Raw material gas } \\
\text { production (mL/g) }\end{array}$ \\
\hline Grinding Group & 1950 & 310 & 332 & 0.06 & 293 \\
\hline Shearing Group & 2000 & 322 & 349 & 0.06 & 300 \\
\hline
\end{tabular}

TS: Total solids, VS: Volatile solids Source: [19]. 


\section{Biogas production potential of elephant grass (Pennisetum Purpureum)}

Elephant grass is a species native to African grasslands and is low in water and nutrient requirements, allowing it to make use of otherwise uncultivated lands [1]. Elephant grass possesses several advantages that make it suitable as bioenergy crop; elephant grass is perennial, it can be vegetative propagated and it can withstand repeated cutting/harvesting and regenerates [20] other features that made elephant grass suitable for bioenergy purposes include the possibility of multiple harvest per year.

\section{Conclusion}

Demand and dependency on fossil fuels have namely been increasing since the industrial revolution. It has become clear that fossil energy sources of the earth are finite, moreover, their use causes more and more damages to the environment (climate change, air pollution, greenhouse effect, etc.). In this context, biogas from biomass will play a vital role in future. Biogas is a versatile renewable energy source, which can be used for replacement of fossil fuels in power and heat production, and it can be used also as gaseous vehicle fuel. Grass biomass growing is importance as it offers extensive environment protection, owing to the capability of grass to sequester carbon into the soil matrix as a result $\mathrm{CO} 2$ emissions reduced. Furthermore, various socioeconomic profits are possible to achieve without compete with food production. Due to their fastest growing rates even in infertile land, low cultivation costs, higher accessibility, consumption of whole plants.

On the other hand, farmers can use grass for biogas production feedstocks and its digestate as fertilizer because it is readily available, it doesn't require any pretreatment, thus helping farmers to reduce their energy cost. Even environmental concerns such as deforestation and ecological damage will not be an issue as the grass which will be cut will grow in a short span of time.

\section{References}

1. Warnars L, Oppenoorth H (2014) A study on bioslurry results and uses. Buku Paket. Terbit Maret. p. 52.

2. Achinas S, Achinas V, Euverink G (2017) A technological overview of biogas production from biowaste. Engineering 3(3): 299-307.

3. Abu-Dahrieh JK, Orozco A, Ahmad M, Rooney D (2011) The Potential for Biogas Production from Grass, Proceedings of the Jordan International Energy Conference, Amman.

4. Amigun B, Musango JK, Stafford W (2011) Biofuels and sustainability in Africa. Renewable and sustainable energy reviews 15(2): 1360-1372.
5. Uzodinma E, Ofoefule A (2009) Biogas production from blends of field grass (Panicum maximum) with some animal wastes. Int. J Phys Sci 4(2): 91-95.

6. Chodkowska-Miszczuk J, Szymańska D (2013) Agricultural biogas plants - A chance for diversification of agriculture in Poland. Renewable and Sustainable Energy Reviews 20: 514-518.

7. Sibiya N, Muzenda E (2014) A review of biogas production optimization from grass silage, International Conference on Chemical Engineering and Advanced Computational Technologies, pp. 24-25.

8. Msibi SS, Kornelius G (2017) Potential for domestic biogas as household energy supply in South Africa. Journal of Energy in Southern Africa 28(2): 1-13.

9. Ionel I, Cioabla A (2010) Biogas production based on agricultural residues. From history to results and perspectives. WSEAS Transactions on Environment and Development 8(6): 591-603.

10. Kwaku E, Kweinor E, Boafo B (2017) Overview of biogas production from different feedstocks. International Journal of Scientific and Research Publications 7(12): 158-164.

11. Jingura RM, Kamusoko R (2017) Methods for determination of biomethane potential of feedstocks: a review. Biofuel Research Journal 4(2): 573-586.

12. Berktay A, Nas B (2007) Biogas production and utilization potential of wastewater treatment sludge. Energy Sources, Part A: Recovery, Utilization, and Environmental Effects 30: 179-188.

13. Hassan EA (2003) Biogas Production from Forage and Sugar Beets: Process Control and Optimization-Ecology and Economy. Univ Kassel, Fachgebiet Agrar technik. p. 2.

14. Yitayal A, Mekibib D, Araya A (2017) Study on Biogas Production Potential of Leaves of Justicia schimperiana and Macro-Nutrients on the Slurry. Int J Waste Resour 7(3): 294.

15. Dussadee N, Ramaraj R, Cheunbarn T (2017) Biotechnological application of sustainable biogas production through dry anaerobic digestion of Napier grass. 3 Biotech 7: 47.

16. Sittijunda S (2015) Biogas production from hydrolysate napier grass by co-digestion with slaughterhouse wastewater using anaerobic mixed cultures. Asia-Pacific Journal of Science and Technology 20(3): 323336.

17. Sawasdee V, Pisutpaisal N (2014) Feasibility of biogas production from napier grass. Energy Procedia 61: 1229-1233.

18. Li Y, Ren X, Dahlquist E, Fan P, Chao T (2014) Biogas potential from Vetiveria zizaniodes (L.) planted for ecological restoration in China. Energy Procedia 61: 2733-2736.

19. Sun P, Zhang W, Yin F, Zhao X, Liu J, et al. (2014). Biogas production potential of transgenic Vetiveria zizanioides in mesophilic batch anaerobic digestion. Scientific Research and Essays 9: 293-296.

20. Ohimain EI, Kendabie P, Nwachukwu RE (2014) Bioenergy potentials of elephant grass, Pennisetum purpureum Schumach. Annual Research \& Review in Biology 4(13): 2215-2227. 
This work is licensed under Creative Commons Attribution 4.0 License

DOI: 10.19080/ARTOAJ.2019.21.556160
Your next submission with Juniper Publishers will reach you the below assets

- Quality Editorial service

- Swift Peer Review

- Reprints availability

- E-prints Service

- Manuscript Podcast for convenient understanding

- Global attainment for your research

- Manuscript accessibility in different formats ( Pdf, E-pub, Full Text, Audio)

- Unceasing customer service

Track the below URL for one-step submission https://juniperpublishers.com/online-submission.php 